\title{
Properties and Processing of Ores Containing Layered Silicates
}

\author{
A. Gerasimov ${ }^{(\bowtie)}$, V. Arsentyev, and V. Lazareva \\ REC Mekhanobr-tekhnica, St-Petersburg, Russia \\ gerasimov_am@npk-mt.spb.ru
}

\begin{abstract}
The solid mineral raw materials of the sediment deposits containing the argillaceous variations such as the coal and the potash ores are the most multi-tonnage solid minerals mined and processed in the territory of the Russian Federation. Both types of the deposits have relatively simple geology aspects with large and medium-sized solids and as a rule, the most often, with the regular bedding which are characterized by the fitchery thickness and the internal structure. Such deposits are very difficult for mining and processing. The thermal modification of this of ores allows changing the physico-chemical properties of its components in such a way that their further processing grinding, separation, transportation and storage can be carried out without the use of process water or significantly reduces its consumption.
\end{abstract}

Keywords: Argillaceous minerals $\cdot$ Hydrochemical modification ·

Thermochemical modification $\cdot$ Water saving

\section{Introduction}

Many deposits of minerals are associated with the presence of layered silicates such as the clay, mudstones, argillaceous slate - highly hydrophilic mineral varieties that have the ability to swell in the water. This ability to self-disperse creates the great difficulties both for the extraction and for the processing of such ores. Since the processing of most minerals is associated with the use of wet processes, where in contact with water the swelling layered silicates are dispersed to a particle size of less than $50 \mu \mathrm{m}$, but due to their high hydrophylic property they form bonds that promote the formation of socalled structured suspensions having increased viscosity. In this case, the structured suspensions make it difficult to perform the separation operations as the classification, the gravity and magnetic separation, the flotation and thickening and filtration operations (Arsentyev et al. 2014).

In order to eliminate the influence of swelling silicates on the treatment processes it is necessary to use the diluted suspensions with the solids content of 10-20\% while the usual solids content in processing suspensions is $35-50 \%$. This causes the increase in 3-4 times the consumption of water during the processing of ores containing the swelling sheet silicates (Zhdanovich et al. 2011).

The most large-tonnage processed commercial mineral containing the swelling silicates are the coal and the potassium salts. Considering these minerals from the point 
of view of their advanced processing, it is important to note the similar processing characteristics:

- comparatively high content of the useful component which is $60-80 \%$ for the bituminous coal and $20-30 \%$ for potassium ores;

- polydispersity of the impregnations of the useful component is from 0.5 to $10 \mathrm{~mm}$;

- relatively low density of the constituent rocks is from 1.4 to $2.3 \mathrm{~g} / \mathrm{cm}^{3}$;

- the presence of argillaceous material such as the layered silicates swelling in the water.

\section{Methods and Approaches}

Coal, sylvinite and kaolin were selected for the dry processing study.

The presented coals are dark gray, dense, laminated and fractured with the matte surface in the place of spalling. The samples of the coal are brittle and under a slight stress are destroyed along the microfracture (Gerasimov et al. 2016).

The sylvinite sample is a rock salt-sylvinite-carnalite formation with the varying ratio of the main rock-forming minerals represented mainly by readily soluble congeries and individuals of the chloride class (Arsentyev et al. 2017a, b).

The kaolin ore is represented by the kaolin argillites mainly gray, dark gray, greenish-gray, less often yellowish-ochreous and sorrel, occasionally milky-gray colors cured during the compaction, dehydration and cementation processes. The structure is massive often the breccia structure and splintery, sometimes the oolitic structure, here and there the indistinctly-banded. The structure is the pelitic, aleuropelitic, aleuropsammito-pelitic, occasionally oolitic (Arsentyev et al. 2017a, b).

\section{Results and Discussion}

The thermal treatment of the high-ash coals (low-temperature pyrolysis reaction) modefies the physicochemical properties of the minerals that make up the ash reducing their ability to swell in water and increasing the magnetic susceptibility which makes it possible to significantly intensify the processes of their magnetic-flotation processing to produce the high-quality solid fuels. In the coal, under the influence of temperatures in the process of the coal pyrolysis, the initial fracture structure is transformed into the cracked-pore structure with the increase in the number and dimensions of the poriness, vesicles and cracks. The sample of the coal subjected to medium-temperature pyrolysis reaction compared to the initial coal has $20 \%$ lower apparent density and the specific energy consumption of crushing is $20-30 \%$ lower.

The specific ash content per unit of the heat of combustion indicates that the combined dry processing of coal allows reducing the specific ash content by 1.3-1.6 times i.e. the formation of the ash and slag during the combustion is reduced.

It has been established that the thermal treatment of the sylvinite ore; containing the argllous-carbonate insoluble minerals in the range of $100-500{ }^{\circ} \mathrm{C}$ practically does not affect the structure of salting minerals of the halite and the silvinite but it significantly 
modifies the structure of minerals entering into the insoluble fraction which has the positive effect on the flotation of these ores and the process of sedimentation of the slurry fractions in the flotation tails.

For reducing the energy costs for the heat treatment of sylvinite ores it has been proposed to use microwave treatment.

The hydrothermal treatment of kaolin raw material in the autoclave can significantly reduce the viscosity of kaolin suspensions and further efficient processing to produce the concentrates for the production of alumina by using the wet screening process for the suspended matters with the relatively high density.

\section{Conclusions}

An analysis of international practice has shown that fresh water is becoming the most scarce resource for the mining and processing industry, which leads to a significant increase in the cost of water supply and circulation systems, with their growth rates being four to five times higher than the growth rates of the ore mining output.

Studies of the problems of reducing water consumption in mineral processing should be combined with energy consumption assessments due to the close relationship between water and energy consumption values within a single processing system of any plant. Most often, a technology that ensures water saving requires higher energy consumption and vice versa.

The presence of layered silicates with mobile crystal lattices in the mined ore significantly complicates both its wet and dry processing.

A promising solution, aimed at efficient use of resources in processing of ores containing layered silicates, implies the inclusion of thermal and hydrothermal modification of such ores as the primary stages of the process chain. These modifications would ensure a reduction or elimination of the negative impact of such materials currently experienced in ore preparation, separation and dewatering and in the storage of processing products.

The solution requires additional energy inputs, but ensures significant savings in other resources.

Acknowledgements. Financial support was provided by the Russian Scientific Fund (project 18-17-00169).

\section{References}

Arsentyev VA, Vaisberg LA, Ustinov ID (2014) Directions of creation of low-water technologies and devices for the processing of finely divided mineral raw materials. Obogashenie Rud (5):3-9

Arsentyev VA, Gerasimov AM, Kotova EL (2017a) Thermochemical modification of sylvinite ore using the microwave heating. Obogashenie Rud (6):3-8

Arsentyev VA, Vaisberg LA, Ustinov ID, Gerasimov AM (2016) Prospects for reducing water use in coal-processing. Mining J (5):97-100 
Arsentyev VA, Gerasimov AM, Mezenin AO (2017b) Study of technology of kaolin processing using hydrothermal modification. Obogashenie Rud (2):3-9

Gerasimov AM, Dmitriev SV (2016) Combined technology of dry coal processing. Obogashenie Rud (6):9-13

Lyskova MY (2016) Geoecology in the modern construction of enterprises for the extraction and enrichment of potassium-magnesium salts, News of Tula State University. Geosciences (4):39-49

Mozheiko FF, Potkin TN (2008) Physico-chemical basis of processing of high-arcilla off-balance sylvinite ores. Vesti, National Academy of Sciences of Belarus, Series of Chemical Sciences, no 4 , pp 25-32

Titkov SN et al (2013) The technology of dry crushing of potash ore to flotation size. In: IX Congress of enrichers of the CIS countries. Collection of materials, vol 2. Digest MISA. M. 2013, pp 578-583

Zhdanovich IB et al (2011) Influence of heat treatment of saliferous arcilla on the structuralgeological properties of their dispersions. Vesti, National Academy of Sciences of Belarus, Series of Chemical Sciences, no 3, pp 113-117

Open Access This chapter is licensed under the terms of the Creative Commons Attribution 4.0 International License (http://creativecommons.org/licenses/by/4.0/), which permits use, sharing, adaptation, distribution and reproduction in any medium or format, as long as you give appropriate credit to the original author(s) and the source, provide a link to the Creative Commons license and indicate if changes were made.

The images or other third party material in this chapter are included in the chapter's Creative Commons license, unless indicated otherwise in a credit line to the material. If material is not included in the chapter's Creative Commons license and your intended use is not permitted by statutory regulation or exceeds the permitted use, you will need to obtain permission directly from the copyright holder.

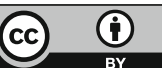

